\title{
Appraising the Physical Environment of Secondary Schools in Calabar, Nigeria
}

\author{
Ogaji $\mathrm{DS}^{1}$, Okokon $\mathrm{EO}^{2}$ \\ ${ }^{1}$ Department of Community Medicine, Niger Delta University, Wilberforce Island, Nigeria \\ ${ }^{2}$ Department of Community Medicine, University of Calabar Teaching Hospital, Calabar, Nigeria
}

\begin{abstract}
Background: Environmental challenges and opportunities vary among schools around the world, across countries and within communities. World Health Organization had reported that the biggest threats to child health and in fact accounting for more than five million deaths each year in children less than 15 years of age are linked to the environment in which they live, learn and play -their homes, schools and their communities. This study assessed the quality of the physical environment of all the secondary schools in Calabar, Cross River State.

Methods: All existing 42 secondary schools in Calabar South local government council and Calabar Municipality; stratified by proprietorship, were rated using pretested quantitative school's physical environment instrument with 4 dimensions; site, structure, classroom and amenities; and various indicators with assigned scores. Data were analysed using various parametric tests.

Results: Overcrowding was observed in 52.4\% of schools. Mean scores of all dimensions was $42.7 \pm 11.4$ from a possible maximum of 73. Mission schools with mean of $49.9 \pm 9.8$ fared better than private $(48.8 \pm 19.8)$ and government $35.5 \pm 11$ respectively. Government owned schools showed consistently lower scores in all study dimensions and the classrooms where students spend most of their time while in school had the worst ratings. The variation between various proprietorship statuses was highest between private and government schools.

Conclusion: Deficiencies observed in the physical environment of the schools, reflects the poor implementation of relevant standards by the supervising authorities and thus, leaving the attaining of a healthy physical environment in schools to the prerogative of the various proprietors.
\end{abstract}

Keywords: Calabar, Nigeria, Physical Environment, School Health Programme, Secondary School.

\section{Introduction}

Environmental challenges and opportunities vary among schools around the world, across countries and within communities. ${ }^{[1]}$ WHO has reported that the biggest threats to children's health, and in fact accounting for greater than 5,000,000 deaths/year in children < 15years are linked to the environment in which they live, learn and play (their home, their school and their community). The above was the reason behind the theme of the 2003 world health day; 'shape the future of live, healthy environment for children' ${ }^{[2]}$ The school environment (including social, psychological and physical factors) had been reported to have significant impact on the health and wellbeing of those who work and study within it, and on their ability to carry out their mandated tasks. ${ }^{[3]}$ Also, it is difficult to teach a child the value of health if the school environment is not conducive to healthy behaviour, and if there are no resources with which to practice health skills. ${ }^{[4]}$ Thus, healthy school environment is an important part of the school health programme in both the three-component model ${ }^{[5]}$ and the CDC eight-component model. ${ }^{[6]}$ A study done in Nigeria by Egbewunmi, Asuzu and Sridhar, revealed that introduction of sanitary waste disposal in a rural community of Elesuin Oyo State, Nigeria lowered the prevalence of helminthiasis among the school children. ${ }^{[7]}$ The six identified groups of environmental hazards that exacerbate the effects of economic under-development and cause the bulk of environment-related deaths and diseases among children are: water security, lack of hygiene and poor sanitation, air pollution, vector-borne diseases, chemical hazards and unintentional injuries or accidents. These should be tackled as priority issues. Hence, effort should be made by the relevant stakeholders to improve the environmental health conditions of their schools in line with available national and local standards. These environmental interventions are however, governed by many factors such as economy, cultural belief and geographic pattern of the community. ${ }^{\left[{ }^{[3}\right.}$

The World Health Organization in its global school health initiative seeks to increase the number of schools that can be called Health-Promoting Schools. ${ }^{[9]}$ For this to be achieved in developing countries, minimum environmental health standards need to be established and enforced. This study is an appraisal of the quality of the physical environment of secondary schools in Calabar. 


\section{Methods}

2.1 Setting of study

The study was conducted in Calabar, the capital of Cross River State, which is comprised of two Local Government Areas namely: Calabar Municipality and Calabar South Local Government Areas in February 2006. The two Local Government Areas are similar in socio-cultural and economic activities with political boundaries as their only distinguishing factor. Calabar located between latitude 4' $58 \mathrm{~N}$ and longitude 8' $17 \mathrm{E}$, is within the tropical rain forest of Nigeria. It has the highest figures of relative air humidity in Nigeria (84\%), mean annual temperature of $26.1{ }^{\circ} \mathrm{C}$ and average rainfall of $307.6 \mathrm{~cm}$. It is bounded in the North by Odukpani Local Government Area, in the West by Calabar River with the Great Qua River at the South and East. At the time of this study, there were 42 secondary schools in both local government areas with 9 and 13 of them being owned by missionary organizations and private individuals, while the remaining 20 were government owned. The coordination of the entire school system including school health services rests on the Ministry of Education and the secondary schools' board. The Nursing department within the State Ministry of Health occasionally posts public health nurses to some of the schoolsto take care of the health needs of the school population.

\subsection{Study instrument}

The status of the schools' physical environment was assessed using a structured quantitative scoring scheme from a previous scheme ${ }^{[10]}$ that was expanded to accommodate the WHO essential components of a healthy school environment. ${ }^{[11]}$ Four dimensions were considered; these were: (a) site/location (b) structure (c) classrooms and (d) available amenities. Each indicator item under these dimensions was assigned scores appropriate to the Nigerian situation. Overcrowding for instance, was said to exist, with a student population > $40 /$ class and/or per capita space of $<10 \mathrm{ft}^{2}$.

Sub-domains in the school physical environment index

- Site indicator - accessibility, topography, absence of nuisance, general safety and security measures.

- Structure indicator - nature of building materials, walls, roofs and floors of schools

- Classroom indicator - per capita space, furniture design and sitting comfort, ventilation, lighting and heat control

- Amenities indicator - source and location of water supply, method of solid and liquid waste disposal, availability of sporting and recreational facilities.

Ethical clearance for this study was obtained from the Research and Ethics Committee of the University of Calabar Teaching Hospital. Permission to access the schools used for this study was obtained from the Commissioner for Education in the State. Following this, the cooperation of the Principal and staff in charge of health in all these schools were sought after due explanation of the purpose of the research and presentation of the entry permit from the Commissioner of Education

\subsection{Pretest}

Pre-testing of the instrument was done at the community secondary school Okoyong, a semi-urban, Efik speaking community in Odukpani Local government Area of Cross River State. It was used to check the relevance, content and reliability of the scale that was designed from extensive literature search and expert reviews.

The reliability of the scale was done by the inter-rater reliability of the scale using the Pearson correlation coefficient which gave a correlation coefficient of 0.84 . Following the pre-testing of the data collection instruments, the research team met to discuss and review their findings and proceeded with appropriate revisions and necessary adaptations of the instruments. Thus, final revisions of the instruments were then prepared for administration in the study area.

\subsection{Data Processing and Analysis}

Quality of the data collected was assessed by it completeness and appropriateness. Data generated from the study were analyzed with the aid of EPI-INFO (Version 2002) epidemiological and statistical software package $(\mathrm{CDC} / \mathrm{WHO})$. Data entered into the computer were checked for accuracy by reading them from the screen, while one of the assistants checked the data source. Data were analyzed and presented in the form of tables and charts. Where necessary, categorical variables were compared using Chi- Square test while quantitative data were analyzed using means, standard deviation, and ANOVA. Games-Howell post-hoc test was used to make multiple comparisons of total scores for different proprietors. The level of significance was set at $\mathrm{p}$-value $\leq 0.05$ and confidence level at $95 \%$. 
III. Result

Table 1: Physical Overcrowding in the Schools' Classroom among the different Owners

\begin{tabular}{llll}
\hline School owner & Overcrowding & & \\
\cline { 2 - 4 } & YES & NO & Total \\
& Frequency $(\%)$ & Frequency $(\%)$ & \\
\hline GOVERNMENT & $18(90.0)$ & $2(10.0)$ & 20 \\
MISSION & $2(22.2)$ & $7(77.8)$ & 9 \\
PRIVATE & $2(15.4)$ & $11(84.6)$ & 13 \\
\hline TOTAL & $22(52.4)$ & $20(47.6)$ & 42 \\
\hline $\mathrm{X}^{2}=21.76$ & $\mathrm{p}=0.000018$ & &
\end{tabular}

Table 1 showed that $90 \%$ of the classrooms in the government schools studied were overcrowded, while; only $22.2 \%$ and $15.4 \%$ of mission and private schools respectively were overcrowded. Overall, $22(52.4 \%)$ of all the schools studied showed overcrowding in the classroom. The relationship between overcrowding and ownership of schools was statistically significant $(p=0.000018)$, with more of the government owned schools being overcrowded.

Table 2: Quantitative Summary Scores of the Physical Environment of the Schools among the different owners

\begin{tabular}{l|lll|l}
\hline Indicator & Government & Mission & \multicolumn{1}{l}{ Private } & All \\
\hline Site & $6.5 \pm 3.6$ & $8.2 \pm 3.8$ & $8.6 \pm 5.4$ & $7.5 \pm 4.6$ \\
& 6 & 8 & 8 & 8 \\
Structure & $8.7 \pm 2.6$ & $10.2 \pm 1.6$ & $10.0 \pm 3.2$ & $9.4 \pm 3.0$ \\
& 8.5 & 10 & 11 & 9 \\
Classroom & $7.6 \pm 5.8$ & $11.4 \pm 3.8$ & $11.9 \pm 5.4$ & $9.8 \pm 6.6$ \\
& 6 & 12 & 11 & 10 \\
Amenities & $12.8 \pm 6.2$ & $20.0 \pm 4.6$ & $18.7 \pm 8.8$ & $16.2 \pm 9.4$ \\
& 13 & 20 & 20 & 15.5 \\
\hline $\begin{array}{l}\text { Total } \\
\text { environment }\end{array}$ & $\mathbf{3 5 . 5}$ & & & \\
\hline
\end{tabular}

Upper values in each cell are the means $\pm 2 \mathrm{SD}$, while the lower values are the median values.

Quantitative assessment of the schools' entire physical environment showed a mean score of 42.7 \pm 19.8 out a possible maximum of 73 . The mission school stratum had the highest mean score of $49.9 \pm 9.8$ $($ median $=51)$, followed by the private schools with a mean of $48.8 \pm 19.8$ (median $=50)$. The government schools had the lowest quantitative score of $35.5 \pm 11.4$ (median $=34$ ). The government owned schools showed lower scores in all the indicators studied. The level of variations within groups was highest for the private schools in most of the indicators assessed except for the classrooms, where this was highest in the government stratum (Table 2).

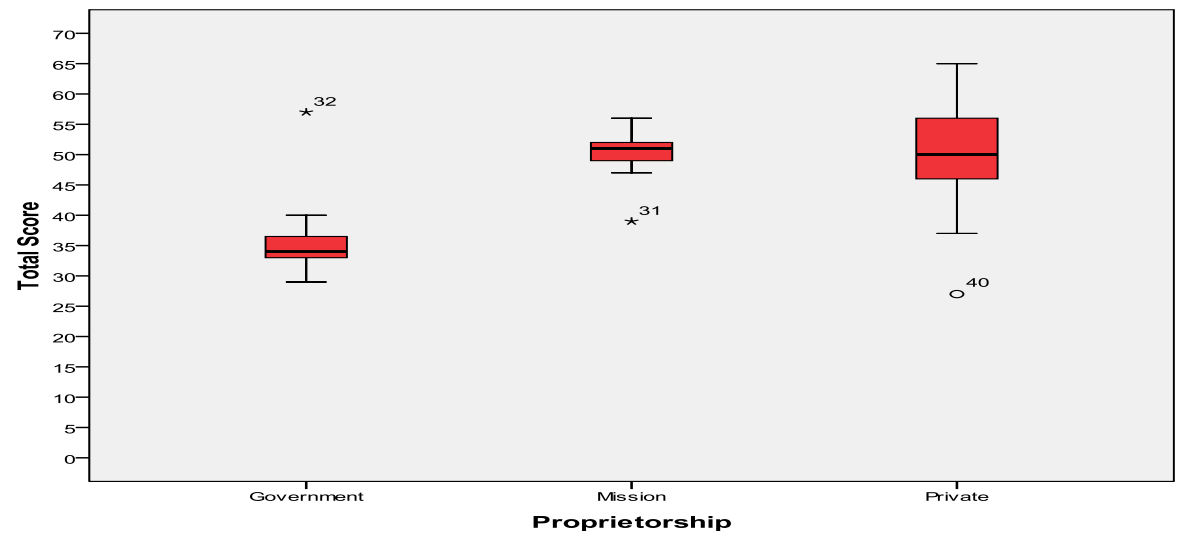

Figure 1: Boxplot showing the entire score of the physical environment according to the different types of school owners 
Legend-The top of the box is at the $75^{\text {th }}$ percentile of the scores, while the bottom of the box is at the 25th percentile of the scores. Box length represents the interquartile range; and the horizontal line through the box represents the median score. The ends of the whiskers represent the largest and smallest values that are not outliers.

The stratum of the private schools had the highest level of variability, and contained the best, and worst ratings of the physical school environment as observed in this study (fig. 1).

Table 3: Relationships between scores of selected indicators of the schools' physical environment and owners using analysis of variance.

* Significant

\begin{tabular}{|c|c|c|}
\hline $\begin{array}{l}\text { School Environment } \\
\text { Category }\end{array}$ & F-statistics & p-value \\
\hline Site & 4.82 & $0.013 *$ \\
\hline Structure & 6.30 & $0.004 *$ \\
\hline Classroom & 12.70 & $0.000^{*}$ \\
\hline Amenities & 18.61 & $0.000 *$ \\
\hline $\begin{array}{l}\text { Entire } \\
\text { environment }\end{array}$ & 19.45 & $0.000 *$ \\
\hline
\end{tabular}

Relationships between the selected environmental indicators and proprietorship of the schools were determined using ANOVA. Scores for the different indicators showed statistically significant differences between proprietors, as did also the summary score.

Table 4.Multiple comparisons of physical environmental variables between schools' owners using GamesHowell Post-Hoc Test.

\begin{tabular}{lllll}
\hline \multirow{2}{*}{ Variable } & Ownership (I) & Ownership (II) & $\begin{array}{l}\text { Mean } \\
\text { Difference }\end{array}$ & p-value \\
\hline Amenity Score & Government & Private & -5.892 & $0.001^{*}$ \\
& Government & Mission & -7.200 & $0.000^{*}$ \\
& Private & Mission & -1.308 & 0.644 \\
\hline Structure & Government & Private & -1.350 & $0.045^{*}$ \\
Score & Government & Mission & -1.572 & $0.002^{*}$ \\
& Private & Mission & -0.222 & 0.904 \\
\hline Classroom Score & Government & Private & -4.323 & $0.000^{*}$ \\
& Government & Mission & -3.844 & $0.001^{*}$ \\
& Private & Mission & 0.479 & 0.878 \\
\hline Location Score & Government & Private & -2.165 & $0.046^{*}$ \\
& Government & Mission & -1.772 & 0.080 \\
& Private & Mission & 0.393 & 0.915 \\
\hline Total Score & Government & Private & -13.319 & $0.001^{*}$ \\
& Government & Mission & -14.439 & $0.000^{*}$ \\
& Private & Mission & -1.120 & 0.935 \\
\hline
\end{tabular}

*Significant

Multiple comparisons showed that higher scores were significantly associated with the private and mission schools in comparison with the government schools for all indicators and dimensions used to assess the schools' physical environment. Apart from the physical siting and location of the schools, all other dimensions investigated revealed statistically significant difference between government and mission/private schools. The strength of this difference is however highest in the provision of health amenities in these schools. The result showed that there is no statistical difference between the scores of the physical environment of the private and the mission schools (Table 3)

\section{Discussion}

The unhealthy state shown by the dismal ratings of the schools' physical environment is a reflection of the generally poor state of the environment in the study area. This unhealthy state had been likened to the poor environmental state of our entire planet. ${ }^{[12]}$ This study showed that less than $50 \%$ of the schools have access to 
safe and adequate water supply, sanitation and sewage disposal systems. Poor environmental conditions comprising unsafe water supply, poor and non-existent sanitation have been recognized as the largest single cause of childhood illness and death. ${ }^{[13]}$ The World Health Organization had identified safe water supply and adequate sanitation as part of the core indicators of monitoring health achievements. ${ }^{[14]}$ Although population growth pattern in most urban cities in developing countries had increased the pressure on available environmental resources, ${ }^{[15]}$ it is still unacceptable to have the school water source a distance of more than 200 metres from the school as was seen in $26.2 \%$ of schools studied.

The mean physical environment score of $42.7+19.8$ out of a possible maximum of 73 indicates a generally low level of environmental conditions prevalent among the schools studied. The classroom environment where the students spend most of their time while in school had the worst rating, due to overcrowding, poor noise and heat control as well as poor indoor air quality. Poor environmental conditions within the classroom had been documented to have a wide range of health implications including the spread of communicable diseases, injuries and mental illnesses ${ }^{[1],[16],[17]}$.

Deducing a statistical association between the environmental score and the proprietorship of schools, showed a consistent significant disadvantage of the government schools, when compared to the private owned schools and thus, places the bulk on the government. The noticeable high level of variation between and within each stratum is suggestive of non-existence or a possibly weak implementation of environmental standards by the supervising authorities and thus, leaving the application of standards at the prerogative of the individual proprietors of schools.

High incidence of accidents and injuries to pedestrians and cyclist would be expected as about a third of these schools are located in busy areas with heavy traffics. Appropriate regulations for the construction of speed breakers and crosswalks markings can however improve safety and mobility for pedestrians. ${ }^{[18]}$

\section{Conclusion}

This study had examined the state of the schools' physical environment in Calabar, and had revealed the poor implementations of relevant standards especially those related to the physical environment of the schools. This had left the different proprietors of schools with the prerogative of using their own standards which the study also showed to be suboptimal in most cases. Improvement in the quality of the school health programme should be a product of improvement in these ranges of quality measures - structural (work force, materials and funding, school environment and profile of health instructions), process (service delivery and an efficient supervision). These would ultimately translate into better health and educational performance for our school-aged adolescents.

Although associations seen in this study are only suggestive because of the study design, a critical look at the evidences can make a significant contribution to a better understanding of the current state of the school health programme to those who need to know. It is hoped that these results will be useful, since they have exposed the deficiencies in the school health programme and provided backing for drawing up measures aimed at mitigating these deficiencies. Furthermore, the implications of these results places a demand on the improvement of existing policies on school health programme as well as the conduct of periodic appraisals.

\section{Reference}

[1] The Physical School Environment; An Essential Component of a Health-Promoting School. WHO Information series on school health, 1995; document 2, WHO, Geneva.

[2] World Health Organization. World Health Day 2003: Shape the future of life, WHO, Geneva, 2003.

[3] World Health Organisation. Information series on school health: oral health promotion through school, WHO Geneva, 2003

[4] Education for health: A manual on health education in primary care. WHO, Geneva, 1988; 134-8.

[5] Allensworth D, Lawson E, Nicholson L, Wyche J. School and Health: our Nation's investment. National Academy Press, Washington DC, 1997:52.

[6] Centers for Disease Control and Prevention. A comprehensive school health program [on-line] Available: http://www.cdc.gov/nccdphp/dash/cshpdef.htm (Accessed on 6th February 2006)

[7] Egbewunmi OO, Asuzu MC, Sridhar MKC. Evaluation of the effect of waste disposal intervention on the prevalence of intestinal helminthes among schoolchildren of Elesu Community, Oyo State. Journal of Community Medicine and Primary Health Care. Vol 7, 1995:69-82.

[8] Ezenwa OA. Comprehensive text on Community Health and Safety in the tropics, safety sciences Lagos; 1995:31-46.

[9] World Health Organisation: Global School Health Initiative; school and youth home page. WHO, Geneva, 2002.

[10] Nwadiuto A, Akani, Nkanginieme K. The school health programme, in :Azubuike JC, Nkanginieme KE - Pediatrics and Child Health in a Tropical Region. African Educational Services, Owerri, Nig. 1999: 510-21.

[11] Amin R, Sato T. Impact of a school-based comprehensive program for pregnant teens on their contraceptive use, future contraceptive intention, and desire for more children. J Community Health Nurs. 2004; 21(1):39-47.

[12] Carol B: Healthy environment for children, an editorial report. Bulletin of the World Health Organization, $2003 ;$ 81(3):157.

[13] Brendis C, Kapphahn C, McCarter V, Wolfe AL. The impact of health insurance status on adolescents' utilization of school-based clinic. J Adolec Health. 1995; 16(1):18-25.

[14] Monekosso MD: District Health Management. Planning, implementation and monitoring a minimum health for all package. WHO-AFRO, 1994.

[15] Mishra CP. Role of education with regard to environmental hygiene and promotional activities. Swasth Hind. 1996; 40(4-5):68-71. 
Appraising The Physical Environment Of Secondary Schools In Calabar, Nigeria

[16] Lucas AO, Gilles HM- School Health Programme. In: Short Textbook of public health medicine for the tropics, $4^{\text {th }}$ edition. Arnold Publishers, London. 2003:332-5.

[17] Krieger J, Higgins DL. Housing and health, 2002; 92(5):758-68.

[18] Leden L, Gerder P, Johansson C. Safe pedestrian crossings for children and elderly. Accid Anal Prev. 2006; 38(2):289-294.

\section{SCORING SCHEME FOR HEALTHFUL PHYSICAL SCHOOL ENVIRONMENT \\ SCHOOL}

\begin{tabular}{|c|c|c|c|}
\hline & DESCRIPTION & SCORE & EMARK \\
\hline \multirow[t]{14}{*}{ LOCATION/SITE } & Presence of link road & 2 & \\
\hline & Suitable Topography & 2 & \\
\hline & Nuisance/health hazards at site & 5 & MAX \\
\hline & ii. Absence of Industrial Pollution & 1 & \\
\hline & iii. Absence of Floods/open drainage & 1 & \\
\hline & iv. Absence of Vectors/pests & 1 & \\
\hline & v. Absence of Animal grazing/dangerous wild animal & 1 & \\
\hline & vi. Absence of other unspecified nuisance/hazards & 1 & \\
\hline & Safety/Security Measure & 5 & MAX \\
\hline & i. Absence of security threat eg high tension wire, bandits & 1 & \\
\hline & ii. School perimeter fence & 1 & \\
\hline & iii. Security/safety team & 1 & \\
\hline & iv. Fire alarms and training & 1 & \\
\hline & v. Fire extinguishers & 1 & \\
\hline TOTAL & & 14 & \\
\hline \multirow[t]{16}{*}{ STRUCTURES } & Material & 2 & MAX \\
\hline & i. Blocks/prefab material & 2 & \\
\hline & ii. Wood/zinc & 1 & \\
\hline & Building wall & 4 & MAX \\
\hline & i. Strong walls, no cracks & 4 & \\
\hline & ii. Strong walls, not plastered or with minor cracks & 3 & \\
\hline & iii. Old walls, with major cracks & 2 & \\
\hline & iv. Dilapidated structures/no walls & 1 & \\
\hline & Roof & 2 & MAX \\
\hline & i. Intact, not leaking & 2 & \\
\hline & ii. Leaking & 1 & \\
\hline & iii. No roof & 0 & \\
\hline & Floor finishing & 3 & MAX \\
\hline & i. Plastered and damp free & 3 & \\
\hline & ii. Worn off, broken and dusty & 2 & \\
\hline & iii. Sandy & 1 & \\
\hline TOTAL & & 11 & \\
\hline \multirow[t]{13}{*}{ CLASSROOM } & Not more than 40 students/class & 1 & \\
\hline & Per capita space not less than $10 \mathrm{ft}^{2}$ & 1 & \\
\hline & Furniture design & 2 & MAX \\
\hline & i. design to match individual students & 1 & \\
\hline & ii. Facility for back rest and desk work & 1 & \\
\hline & Sitting comfort & 2 & MAX \\
\hline & i. $100 \%$ seated on desks & 2 & \\
\hline & $<100 \%$ seated on desks & 1 & \\
\hline & none seated & 0 & \\
\hline & Ventilation & 4 & MAX \\
\hline & i. Door and window area not less than $25 \%$ of floor area & 1 & \\
\hline & ii. Doors and windows opening on different walls & 1 & \\
\hline & iii. Controllable ventilation with intact doors and windows & 1 & \\
\hline
\end{tabular}


Appraising The Physical Environment Of Secondary Schools In Calabar, Nigeria

\begin{tabular}{|c|c|c|c|}
\hline & iv. With supplemental ventilation & 1 & \\
\hline & Lighting & 3 & MAX \\
\hline & i. Adequate & 2 & \\
\hline & ii. Inadequate & 1 & \\
\hline & iii. with supplemental artificial lighting (add) & 1 & \\
\hline & Heat control & 2 & MAX \\
\hline & i. Classroom properly ceiled & 2 & \\
\hline & ii. Classroom partially ceiled & 1 & \\
\hline & iii. No ceiling & 0 & \\
\hline & Facility for hand washing & 1 & \\
\hline & Drinking fountains, buckets and cups in class & 1 & \\
\hline & Dustbin/Waste paper basket for refuse collection & 1 & \\
\hline TOTAL & & 18 & \\
\hline AMENITIES & Cleanliness/Aesthetics of the entire environment & 4 & \\
\hline & Water supply & & \\
\hline & a) Source - & 4 & MAX \\
\hline & i. pipe borne/treated water & 4 & \\
\hline & ii. Borehole/mono pump & 3 & \\
\hline & iii. Wells & 2 & \\
\hline & iv. Surface water & 1 & \\
\hline & v. Nil & 0 & \\
\hline & b) Location - & 3 & MAX \\
\hline & i. within the school & 3 & \\
\hline & ii. $<200$ metres outside school & 2 & \\
\hline & iii. >200metres outside school & 1 & \\
\hline & Solid waste Disposal Method & 4 & MAX \\
\hline & i. incinerator & 4 & \\
\hline & ii. Sanitary landfill & 3 & \\
\hline & iii. Composting & 2 & \\
\hline & iv. Open dumping/burning & 1 & \\
\hline & Sewage Disposal System & & \\
\hline & a) Toilet type & 3 & MAX \\
\hline & i. Water closet/septic tank & 3 & \\
\hline & ii. Pit trench & 2 & \\
\hline & iii. Bucket & 1 & \\
\hline & iv. None & 0 & \\
\hline & b) Toilet-student ratio & 5 & MAX \\
\hline & i. $1:<30$ & 5 & \\
\hline & ii $1: 31-45$ & 4 & \\
\hline & iii. $1: 46-60$ & 3 & \\
\hline & iv. $1: 61-90$ & 2 & \\
\hline & v. $1:>90$ & 1 & \\
\hline & vi. None & 0 & \\
\hline & Availability of Eating room/Canteen & 2 & \\
\hline & Sports field available & 2 & \\
\hline & Sporting facilities & 3 & MAX \\
\hline & Available and adequate & 3 & \\
\hline & Available but inadequate & 1 & \\
\hline & Not available & 0 & \\
\hline TOTAL & & 30 & \\
\hline \multicolumn{2}{|c|}{ GRAND TOTAL } & 73 & \\
\hline
\end{tabular}

